\title{
The Dynamics of Mortgage Debt in Default
}

Helu Jiang, Technical Research Associate

Juan M. Sánchez, Research Officer and Economist

T he large decrease in house prices between 2006 and 2011 led to a dramatic increase in mortgage debt defaults. Since then, the share of mortgage debt in default has decreased significantly and is now close to the pre-2006 level. In this essay, we argue that these fluctuations are predominantly the consequence of changes in the number of households falling behind in their mortgage payments (the extensive margin) and not changes in the amount of debt of those in default (the intensive margin). On average, the extensive margin accounts for 78 percent of the increase in the 2006-09 period and 93 percent of the decrease in the 2011-15 period. This information may be useful in designing prudential policies to mitigate mortgage default.

Rapid declines in house prices, negative home equity, and the number of households in default all contributed to the dramatic increase in mortgage defaults during the Great Recession.

The analysis is performed using data from the Federal Reserve Bank of New York Consumer Credit Panel/Equifax. In our measure of default, we consider all households with mortgage payments 120 or more days late. Figure 1 shows the share of mortgage debt in default, which fluctuated between 0.7 percent and 1 percent in the 1999-2006 period and then jumped to 7.5 percent in 2009. ${ }^{1}$ The figure also shows the evolution of house prices, whose collapse coincided with increasing mortgage defaults. In a recent article, Hatchondo, Martinez, and Sánchez (2015) show how these two series are related: A rapid decrease in house prices causes a sharp increase in mortgage defaults because more households find themselves with negative home equity ("under water"), and some of these households find it beneficial to default after a negative shock to income (i.e., unemployment).

We decompose the changes in the share of debt in default into changes in four different components: average debt in default, number of households in default, average debt, and number of households with debt. Basically, since

\author{
Share of debt in default $=\frac{\text { Debt in default }}{\text { Total debt }}$ \\ $=\frac{\text { Average debt in default } \times \text { Number of households in default }}{\text { Average debt } \times \text { Number of households with debt }}$,
}

we can compute the percentage change $(\% \Delta)$ in the share of debt in default as follows:

$$
\begin{aligned}
& \% \Delta(\text { Share of debt in default }) \\
& =\% \Delta(\text { Average debt in default }) \\
& +\% \Delta(\text { Number of households in default }) \\
& -\% \Delta(\text { Average debt }) \% \Delta(\text { Number of households with debt })
\end{aligned}
$$

Figure 2 shows the results of the decomposition by year; the four colors in each column represent the changes in the four components. The percentage value (shown on the left vertical axis) illustrates the change in the share of debt in default generated by the changes in a particular component. According to the previous equations, the summation of changes in the four components equals the changes in the share of debt in default (represented by the values for the black dots as shown on the right axis). For example, the black dot for 2006-07 has a value of 92, which indicates that the share of debt in default increased by 92 percent in that time period.

There are three interesting findings. First, and most importantly, we find that fluctuations in the number of households in default accounted for most of the fluctuations in the share of debt in default (shown by the size of the orange part of the bars in Figure 2). The share of households in default was very large not only for the years when defaults were increasing (2006 to 2009), but also for the subsequent years when the share of debt in default decreased slowly but steadily. The changes in the number of households in default confirm our earlier claim that the drastic decline in house prices between 2006 and 2009 caused negative home equity for more households. For some of these households a negative income shock triggered default, thus leading to the sharp increase in mortgage debt default. Another reason for this pattern is the delay in foreclosure 


\section{Figure 1}

\section{Evolution of Mortgage Debt in Default and House Prices}

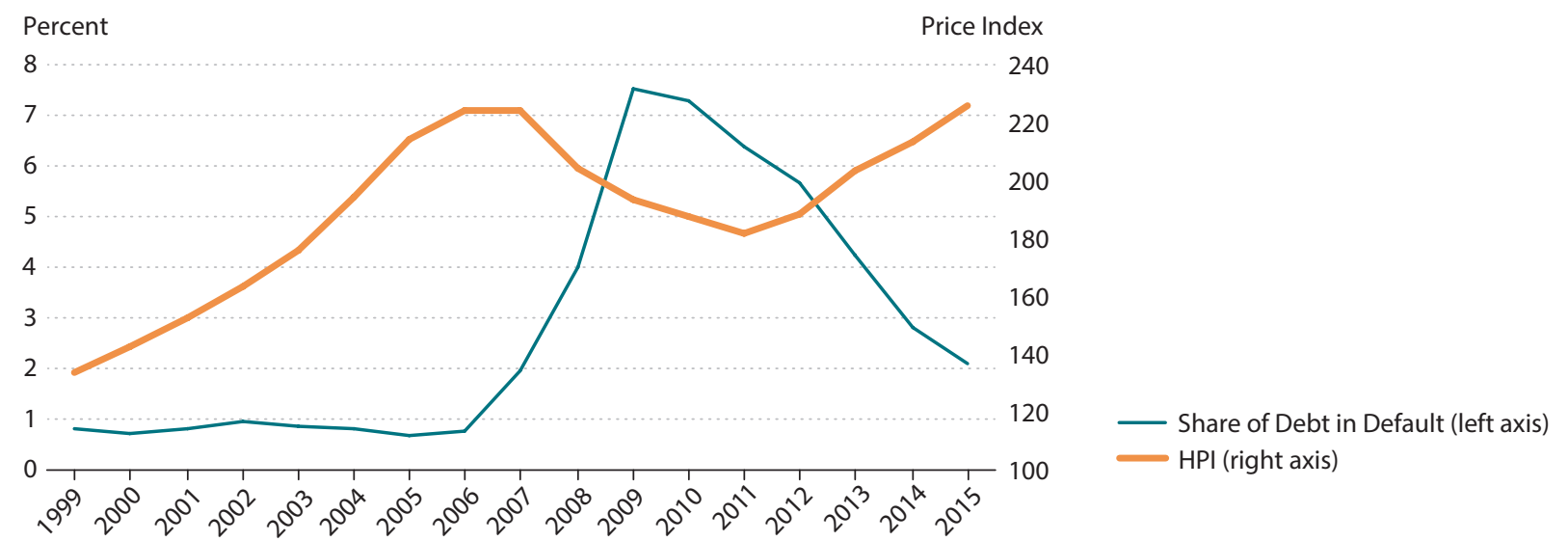

SOURCE: Federal Reserve Bank of New York Consumer Credit Panel/Equifax and Federal Housing Finance Agency (FHFA) House Price Index (HPI). ${ }^{2}$

\section{Figure 2}

\section{Decomposing Changes in the Share of Debt in Default}

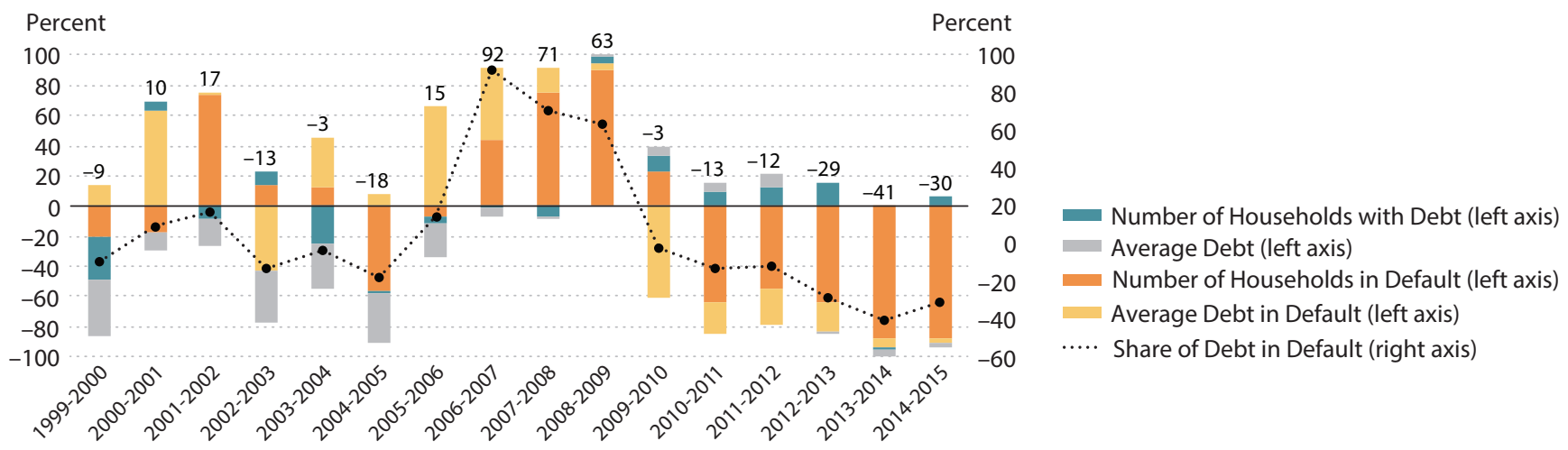

NOTE: "Households with debt" are defined as households with a positive mortgage total balance, a positive mortgage current balance, or those with mortgage payments that are 30 or more days late. "Households in default" are defined as all households whose mortgage payments are 120 or more days late.

SOURCE: Federal Reserve Bank of New York Consumer Credit Panel/Equifax.

proceedings that started during the Great Recession.

Chan et al. (2015) show that borrowers' knowledge of a possible long delay between the formal notice of foreclosure and the actual foreclosure sale date affects the likelihood of default: Borrowers who anticipate a longer period of "free rent" have a greater incentive to default on their mortgages.

Second, our results indicate that from 2003 to 2007 the average amount of debt (the gray part of the bars in Figure 2) exerted downward pressure on the share of debt in default. That is, since the average amount of debt was increasing, if the other three components had not increased, the share of debt in default would have decreased.

Finally, we find that the average amount of debt in default (the yellow part of the bars in Figure 2) was important in the 2006-08 period. This finding indicates that part of the increase in the share of debt in default during that period was actually due to an increase in the amount of the debt of households in default. This increase is in line with the fact that the decline in house prices affected households with larger debt (not necessarily subprime loans) that were not falling into default before 2006. When house 
prices plummeted in 2006, more households from this group defaulted. Later in the recession, the importance of the average amount of debt was overtaken by the number of households in default as more and more households with similar characteristics chose to default.

To summarize, the rapid increases in mortgage debt in default between 2006 and 2011 captured the attention of the public, policymakers, and researchers. It is important to understand the main forces driving the default increase, especially in designing prudential policies that minimize mortgage default such as those analyzed by Hatchondo, Martinez, and Sánchez (2015). The decomposition exercise in this essay suggests that the evolution of the share of mortgage debt in default can be accounted for mostly by changes in the number of households in default rather than changes in the overall amount of mortgage debt and the number of households with mortgages. Changes in the amount of debt in default also played a nonnegligible role, especially during the pre-crisis to early crisis periods.

\section{Notes}

1 In this article, the data refer to the third quarter of each year because the latest data available are for the third quarter of 2015.

2 The FHFA HPI uses data provided by the Federal National Mortgage Association (Fannie Mae) and the Federal Home Loan Mortgage Corporation (Freddie Mac). Quarterly data on purchase-only indexes can be retrieved from http://www.fhfa.gov/DataTools/Downloads/Pages/House-Price-IndexDatasets.aspx\#qat.

\section{References}

Chan, Sewin; Haughwout, Andrew; Hayashi, Andrew and Van der Klaauw, Wilbert. "Determinants of Mortgage Default and Consumer Credit Use: The Effects of Foreclosure Laws and Foreclosure Delays." Staff Report No. 732, Federal Reserve Bank of New York, June 2015;

https://www.newyorkfed.org/medialibrary/media/research/staff_reports/sr7 32.pdf.

Hatchondo, Juan Carlos; Martinez, Leonardo and Sánchez, Juan M. "Mortgage Defaults." Journal of Monetary Economics, November 2015, 76, pp. 173-90. 